\title{
Uji Aktivitas Antikolesterol Ekstrak Etanol Daun Patikan Emas (Euphorbia prunifolia Jacq.) pada Tikus Wistar yang Hiperkolesterolemia
}

\author{
Nadhilah Bachmida*, Meiske S. Sangia, Julius S. Pontoha \\ aJurusan Kimia, FMIPA, Unsrat, Manado
}

KATA K UN C I

Euphorbia prunifolia Jacq. Antikolesterol

Metode

amperometrik

\section{K E YW O R D S}

Euphorbia prunifolia Jacq.

Anticholesterol

Amperometric

methods

\section{biosensor}

AVAILABLE ONLINE

10 Februari 2015

\begin{abstract}
A B S T R A K
Telah dilakukan penelitian untuk menentukan aktivitas antikolesterol ekstrak etanol daun patikan emas pada tikus wistar yang hiperkolesterolemia. Tikus wistar jantan yang berusia 2-3 bulan sebanyak 20 ekor dibagi menjadi 4 kelompok perlakuan secara acak. Kelompok $\mathrm{K}$ diberi pakan beras jagung, sedangkan kelompok $\mathrm{K}-, \mathrm{P}_{1}$, dan $\mathrm{P}_{2}$ diberi pakan aterogenik. Kelompok $\mathrm{P}_{1}$ dan $\mathrm{P}_{2}$ diberi ekstrak dengan dosis 10 dan $30 \mathrm{mg} / \mathrm{kgBB}$. Pemeriksaan kadar kolesterol plasma ditentukan dengan metode biosensor amperometrik menggunakan alat ukur NESCO GCU dengan bantuan strip yang telah ditetesi darah. Darah tikus diperoleh dari bagian ekor yang telah dilukai. Data yang diperoleh dianalisis menggunakan ANOVA satu arah $(p<0,05)$. Hasil penelitian menunjukkan ekstrak etanol daun patikan emas dengan dosis 10 dan $30 \mathrm{mg} / \mathrm{kgBB}$ memiliki aktivitas antikolesterol dengan penurunan kadar kolesterol sebesar 12 dan $71 \%$ dibandingkan dengan kelompok K-.

A B S T R A C T
\end{abstract}

Research had been carried out to determine anticholesterol activity of ethanol extract gold patikan leaves. 20 Male wistar rats aged 2-3 months were divided into 4 groups randomly. $K$ group with corn rice fed, while the $\mathrm{K}-, \mathrm{P}_{1}$ and $\mathrm{P}_{2}$ with atherogenic fed. Group $\mathrm{P}_{1}$ and $\mathrm{P}_{2}$ are given with extract with doses 10 and $30 \mathrm{mg} / \mathrm{kgBW}$. Examination of plasma cholesterol levels were determined by amperometric biosensor methods using a measuring instrument NESCO GCU with strip that had spilled blood. Blood was obtained from rats tail that had been injured. Data were analyzed using one-way ANOVA $(p<0,05)$. The results showed that the ethanol extract of gold patikan leaves with doses 10 and $30 \mathrm{mg} / \mathrm{kgBW}$ decrease the anticholesterol activity with cholesterol levels by 12 and $71 \%$, compared with K-group.

\section{Pendahuluan}

Gaya hidup yang semakin modern mendorong masyarakat cenderung memilih cara instan dalam melakukan banyak hal, salah satunya dalam memilih makanan. Mengkonsumsi makanan cepat saji yang biasanya tinggi akan lemak namun minim akan serat, saat ini telah menjadi salah satu kebiasaan yang mulai membudaya di Indonesia. Menurut Murray et al. (2003) makan makanan cepat saji yang biasanya kita jumpai dalam bentuk gorengan, dapat mengakibatkan terjadinya peningkatkan kadar kolesterol total dalam plasma darah.

Kolesterol merupakan suatu alkohol steroid atau sterol utama pada jaringan hewan, yang tersebar luas di dalam semua sel tubuh khususnya di dalam jaringan saraf. Senyawa ini berperan penting dalam membran plasma dan lipoprotein plasma dan juga sebagai prekursor hormon korteks adrenal serta hormon seks, vitamin D dan asam empedu (Murray et al., 2003). Hiperkolesterolemia merupakan gangguan metabolisme kolesterol yang terjadi karena adanya

*Corresponding author: Jurusan Kimia FMIPA UNSRAT, Jl. Kampus Unsrat, Manado, Indonesia 95115; Email address: nadhilahbachmid@gmail.com Published by FMIPA UNSRAT (2015) 
peningkatan kadar kolesterol LDL dalam darah yang telah melewati batas normal (Visavadiya et al., 2005). Hiperkolesterolemia dapat menyebabkan penyakit kardiovaskuler dan aterosklerosis (Richardson et al., 2005). Aterosklerosis merupakan penumpukan lemak kolesterol pada pembuluh darah, yang mengakibatkan terjadinya penebalan pada dinding pembuluh darah dan hilangnya elastisitas arteri yang berdampak pada penyempitan pembuluh darah atau arteriosklerosis. Arteriosklerosis dapat menyerang arteri pada otak, jantung, ginjal dan organ vital lainnya (Thacker et al., 2005).

Secara umum penelitian dengan menggunakan obat hiperkolesterolemia pada hewan uji berhasil dalam mengendalikan dan menurunkan kadar kolesterol dalam darah, namun penggunaan obat hiperkolesterolemia dalam jangka panjang dapat menimbulkan efek samping (Nafrialdi, 2007). Untuk itu, penggunaan obat tradisional merupakan cara pengobatan dan pencegahan yang dinilai tepat dalam mengendalikan dan menurunkan kadar kolesterol dalam darah yang sudah sejak lama digunakan oleh masyarakat Indonesia.

Menurut informasi yang diperoleh dari masyarakat Sulawesi Utara tepatnya di daerah Tomohon, patikan emas dimanfaatkan sebagai obat tradisional karena dipercaya mampu menurunkan kadar kolesterol darah. Patikan emas merupakan gulma yang tumbuh tahunan, dan biasanya tumbuh di pertanaman jagung, gandum, tebu, singkong dan kacang tanah (Holm et al., 1997). Gulma merupakan tumbuhan yang tidak diinginkan kehadirannya karena dapat mengganggu pertumbuhan tumbuhan utama, namun berdasarkan informasi yang diperoleh dari masyarakat, tumbuhan ini justru dimanfaatkan tidak hanya sebagai obat tradisional, daun ini juga sering dijadikan sayuran tambahan pada bubur manado. Bagian tumbuhan yang dimanfaatkan adalah daun dan akar. Sejauh ini belum ada penelitian secara ilmiah mengenai pemanfaatan tumbuhan ini sebagai agen antikolesterol tubuh. Kemampuan daun patikan emas sebagai agen antikolesterol tersebut dapat diperoleh dengan menggunakan tikus wistar sebagai hewan uji.

Besarnya dampak kolesterol bagi tubuh dan potensi daun patikan emas dalam menurunkan kadar kolesterol darah serta belum adanya penelitian ilmiah mengenai kemampuan daun patikan emas sebagai agen antikolesterol dalam tubuh, sehingga perlu dilakukannya suatu penelitian ilmiah mengenai aktivitas antikolesterol ekstrak daun patikan emas pada tikus wistar yang hiperkolesterolemia. Penelitian ini bertujuan untuk menentukan aktivitas antikolesterol ekstrak etanol daun patikan emas pada tikus wistar yang hiperkolesterolemia.

\section{Metode}

\subsection{Bahan dan Metode}

Bahan yang digunakan dalam penelitian ini adalah daun patikan emas, etanol, Carboxy Methyl Cellulose (CMC) 0,5\% (m/v) dan akuades. Hewan uji yang digunakan adalah tikus putih galur wistar jantan yang berusia 2-3 bulan sebanyak 20 ekor dengan pakan tikus berupa beras jagung. Alat yang digunakan adalah oven (Mammert) disposable syringe $3 \mathrm{~mL}$ (Terumo), nasogastric tube (NGT) $35 \mathrm{~cm}$, kit dan strip kolesterol NESCO Glucose Cholesterol Uric acid (GCU) dan kandang tikus beserta kelengkapannya.

\subsection{Preparasi dan Ekstraksi Daun Patikan Emas}

Sampel segar daun patikan emas dicuci, dipotong, kemudian dikeringanginkan. Sampel yang telah kering digiling sampai halus, kemudian diayak dengan ayakan 60 mesh. Sebanyak 100 g serbuk daun patikan emas diekstraksi dengan cara dimaserasi pada suhu ruang dengan menggunakan $500 \mathrm{~mL}$ etanol $80 \%$ selama 48 jam, selanjutnya sampel disaring dengan menggunakan kertas saring. Filtrat yang diperoleh diuapkan pada suhu $78^{\circ} \mathrm{C}$ dengan cara dievaporasi hingga diperoleh ekstrak kental daun patikan emas. Ekstrak kental yang telah diperoleh dikeringkan dalam oven dengan suhu $40^{\circ} \mathrm{C}$ selama 72 jam sehingga diperoleh ekstrak kering daun patikan emas.

\subsection{Pembuatan Pakan Aterogenik}

Pakan aterogenik dibuat dengan mencampurkan $100 \mathrm{~g}$ lemak kambing, $50 \mathrm{~g}$ kuning telur dan beras jagung. Lemak kambing dipanaskan terlebih dahulu hingga mencair dan telur yang telah direbus diambil kuning telurnya, kemudian dicampurkan dengan beras jagung hingga 1000 g (Gani et al., 2013).

\subsection{Penyiapan dan Perlakuan Hewan Uji}

Tikus wistar yang digunakan berjumlah 20 ekor. Tikus wistar yang digunakan hanya yang berjenis kelamin jantan, karena dikhawatirkan akan terjadi kesalahan dalam pengukuran kadar kolesterol akibat pengaruh dari sistem hormonal, karena pada tikus betina akan terjadi peningkatan hormon estrogen pada masa menstruasi. Tikus diaklimasikan terlebih dahulu selama 7 hari agar terbiasa dengan kondisi laboratorium. Selama masa aklimasi, tikus wistar diberi pakan beras jagung dan air secara ad libitum.

Setelah masa aklimasi, semua tikus dipuasakan selama 12-14 jam. Menurut Murray et al. (2003) proses puasa ini bertujuan untuk menurunkan aktivitas HMG-KoA reduktase secara nyata dan menurunkan sintesis kolesterol eksogen. Pada hari ke-8, semua tikus yang telah dipuasakan, diambil sampel darahnya melalui vena ekor, untuk pengujian total plasma kolesterol awal tikus. Tikus kemudian dibagi menjadi 4 kelompok perlakuan secara acak, yaitu kelompok tikus hiperkolesterolemia dengan pakan aterogenik (K-), kelompok tikus dengan beras jagung (K) dan kelompok tikus hiperkolesterolemia dengan pakan aterogenik dan ekstrak etanol daun patikan emas $(\mathrm{P})$ dengan dosis $10 \mathrm{mg} / \mathrm{kgBB}$ dan 30 $\mathrm{mg} / \mathrm{kgBB}$. Masing-masing kelompok perlakuan terdiri dari 5 ekor tikus.

\subsection{Penginduksian Ekstrak pada Tikus Wistar}

Ekstrak kering daun patikan emas ditimbang sesuai dengan perhitungan dosis pada masingmasing tikus wistar. Ekstrak yang telah ditimbang, 
disuspensikan dengan CMC 0,5\% (m/v). Menurut Delgado (1982), penggunaan CMC tidak akan berpengaruh terhadap perubahan kadar kolesterol total darah karena CMC tidak dicerna dan diabsorpsi oleh tubuh.

Ekstrak yang telah disuspensikan kemudian diinduksi ke dalam tubuh tikus wistar menggunakan NGT atau sonde lambung. Proses induksi ini dilakukan setiap hari, selama masa perlakuan.

\subsection{Pengambilan Sampel Darah Tikus Wistar}

Pemeriksaan sampel darah tikus wistar dilakukan dalam lima tahapan yaitu, setelah masa aklimasi (minggu ke-0) dan selama proses perlakuan yaitu pada minggu ke-1, 2, 4 dan ke-6. Tikus yang akan diambil sampel darahnya dipuasakan terlebih dahulu selama 12-14 jam. Ekor tikus wistar dibersihkan dengan kapas yang telah diberi alkohol $70 \%$, agar kotoran yang terdapat pada ekor bisa terangkat dan sebagai sterilisasi ekor tikus sebelum melakukan pengambilan sampel darah. Selanjutnya darah diambil beberapa tetes pada bagian ekor yang telah dilukai. Proses ini dilakukan tanpa memberikan anastesi terlebih dahulu. Darah kemudian diteteskan pada strip pengujian kolesterol.

\subsection{Pemeriksaan Kadar Kolesterol Total Plasma Darah}

Kadar kolesterol total plasma darah ditentukan dengan menggunakan alat ukur NESCO GCU dengan kisaran pemeriksaan 100-400 mg/dL.

\subsection{Analisis Data}

Analisis data penelitian dilakukan dengan membandingkan data antara kelompok perlakuan dengan uji ANOVA satu arah menggunakan program SPSS 17.0. ANOVA satu arah dianggap berbeda nyata secara statistika jika didapatkan harga $p<0,05$ dengan tingkat kepercayaan 95\% $(\alpha=0,05)$.

\section{Hasil dan Pembahasan \\ 3.1. Pengaruh Pakan Aterogenik terhadap Bobot Badan Tikus}

Pakan aterogenik merupakan pakan yang sengaja dibuat untuk meningkatkan kadar kolesterol darah hewan uji. Menurut Lestari dan Muchtadi dalam Hardiningsih dan Nurhidayat (2006), makanan untuk meningkatkan kadar kolesterol darah tikus terdiri atas 1,5\% kuning telur ayam, lemak kambing 10\% dan minyak kelapa $1 \%$. Pada penelitian ini pakan aterogenik dibuat dari 5\% kuning telur ayam dan $10 \%$ lemak kambing.

Menurut Soedarsono dan Atmomarsono (1983), kuning telur mengandung banyak kolesterol, mampu meningkatkan jumlah kolesterol dalam serum dan akan terjadi penurunan kolesterol yang nyata, apabila pemberian kuning telur dihentikan. Berdasarkan hasil penelitian yang telah dilakukan oleh Saidin (1999), kadar kolesterol pada 100 g kuning telur mencapai $485 \mathrm{mg}$. Hasil yang berbeda dilaporkan oleh Hardiningsih dan Nurhidayat (2006), yang menyebutkan bahwa kadar kolesterol kuning telur adalah 369,2 mg/100 g kuning telur. Sedangkan kadar kolesterol pada lemak kambing adalah 3,2 $\mathrm{mg} / \mathrm{g}$ atau $320 \mathrm{mg} / 100 \mathrm{~g}$ lemak kambing (Das et al., 2009). Jumlah pakan harian yang dikonsumsi tikus wistar disajikan dalam tabel 1.

\section{Tabel 1 - Berat Pakan Harian yang dikonsumsi}

\begin{tabular}{|c|c|}
\hline Kelompok Perlakuan & Berat Pakan Harian yang dikonsumsi (g) \\
\hline $\mathrm{K}$ & $10,46 \pm 0,99^{\mathrm{a}}$ \\
\hline $\mathrm{K}-$ & $15,86 \pm 5,40^{\mathrm{bc}}$ \\
\hline $\mathrm{P}_{1}$ & $17,56 \pm 4,68^{\mathrm{bc}}$ \\
\hline $\mathrm{P}_{2}$ & $14,66 \pm 4,00^{\mathrm{abc}}$ \\
\hline
\end{tabular}

Keterangan : $P_{1}$ : pemberian ekstrak daun patikan emas dengan dosis $10 \mathrm{mg} / \mathrm{kgBB}$. $\mathrm{P}_{2}$ : pemberian ekstrak daun patikan emas dengan dosis $30 \mathrm{mg} / \mathrm{kgBB}$. Huruf yang berbeda menunjukkan hasil dengan perbedaan yang nyata secara statistika.

Dari tabel diatas (Tabel 1) kelompok $\mathrm{P}_{1}$ yang diberi pakan aterogenik memiliki rata-rata konsumsi pakan harian terbesar dibandingkan dengan kelompok perlakuan lain, sedangkan rata-rata konsumsi pakan harian terkecil terdapat pada kelompok $\mathrm{K}$ yang hanya diberi pakan beras jagung. Sehingga dapat dikatakan bahwa, berdasarkan data di atas (Tabel 1) tikus wistar dalam penelitian ini lebih menyukai pakan aterogenik dibandingkan dengan beras jagung. Besarnya konsumsi pakan aterogenik ini akan berdampak pada peningkatan kadar kolesterol total dalam darah. Hal ini sejalan dengan Chenoweth et al. (1981) yang menyimpulkan bahwa, konsentrasi kolesterol total dalam darah meningkat pada pemberian kuning telur, dan peningkatan akan sesuai dengan persentase lemak yang diberikan.

Perkembangan bobot badan tikus selama masa perlakuan dapat dilihat pada tabel 2. Berdasarkan tabel di atas (Tabel 2), bobot badan tikus cenderung mengalami peningkatan. Hal ini mungkin disebabkan karena kelompok $\mathrm{K}-, \mathrm{P}_{1}$, dan $\mathrm{P}_{2}$ diberi pakan aterogenik yang mengandung kolesterol sehingga peningkatan bobot badannya lebih besar dibandingkan dengan kelompok K. Kelompok K ratarata mengalami peningkatan bobot badan sebesar $7,8 \mathrm{~g}$, sedangkan kelompok $\mathrm{K}-, \mathrm{P}_{1}$ dan $\mathrm{P}_{2}$ masing- 
masing mengalami peningkatan bobot badan sebesar 8,4 g, 13,9 g dan 13,9 g. Variasi peningkatan bobot badan tikus wistar pada kelompok perlakuan yang diberi pakan aterogenik ini mungkin disebabkan karena adanya variasi genetik yang memungkinkan adanya perbedaan respon tubuh yang berbeda terhadap pakan yang diberikan.

Tabel 2 - Perkembangan Bobot Badan Tikus

\begin{tabular}{|c|c|c|c|c|c|c|c|}
\hline \multirow{2}{*}{$\begin{array}{l}\text { Kelompok } \\
\text { Perlakuan }\end{array}$} & \multicolumn{5}{|c|}{ Bobot Badan Tikus (g) pada Minggu Ke- } & \multirow{2}{*}{$\begin{array}{l}\text { Rata-rata Bobot Badan } \\
\text { Tikus (g) } \pm \text { SD }\end{array}$} & \multirow{2}{*}{$\begin{array}{c}\text { Rata-rata Kenaikan Bobot } \\
\text { Badan Tikus (g)/ Minggu } \\
\text { Pengujian }\end{array}$} \\
\hline & 0 & 1 & 2 & 4 & 6 & & \\
\hline $\mathrm{K}$ & 155,0 & 162,3 & 170,2 & 178,3 & 186,1 & $170,4 \pm 12,37$ & 7,8 \\
\hline K- & 132,0 & 143,4 & 150,4 & 163,2 & 165,4 & $150,9 \pm 13,92$ & 8,4 \\
\hline $\mathrm{P}_{1}$ & 128,2 & 136,4 & 145,2 & 176,0 & 183,9 & $153,9 \pm 24,65$ & 13,9 \\
\hline $\mathrm{P}_{2}$ & 146,9 & 158,7 & 170,0 & 193,5 & 202,6 & $174,3 \pm 23,36$ & 13,9 \\
\hline
\end{tabular}

Keterangan : $\mathrm{P}_{1}$ : pemberian ekstrak daun patikan emas dengan dosis $10 \mathrm{mg} / \mathrm{kgBB}$. $\mathrm{P}_{2}$ : pemberian ekstrak daun patikan emas dengan dosis $30 \mathrm{mg} / \mathrm{kgBB}$. Minggu ke-0: setelah aklimasi. Minggu ke-1 sampai ke-6: pemberian perlakuan.

\subsection{Kadar Kolesterol Total}

Penelitian ini menggunakan tikus wistar karena metabolisme kolesterol pada tikus wistar mirip dengan metabolisme kolesterol pada manusia. LDL dan HDL pada tikus putih dan manusia memiliki fungsi yang sama yaitu untuk memproduksi steroid dan apolipoprotein yang sama (Gwynee dan Hess, 2000). Pemberian pakan aterogenik berupa lemak kambing dan kuning telur ayam dapat meningkatkan kadar kolesterol total darah tikus putih. Hal ini sejalan dengan penelitian yang telah dilakukan oleh Gani et al. (2013) yang melaporkan bahwa, pemberian pakan aterogenik berupa lemak kambing dan kuning telur dapat meningkatkan kadar LDL dalam darah secara nyata. Kadar kolesterol total tikus wistar selama masa perlakuan disajikan dalam gambar 1.

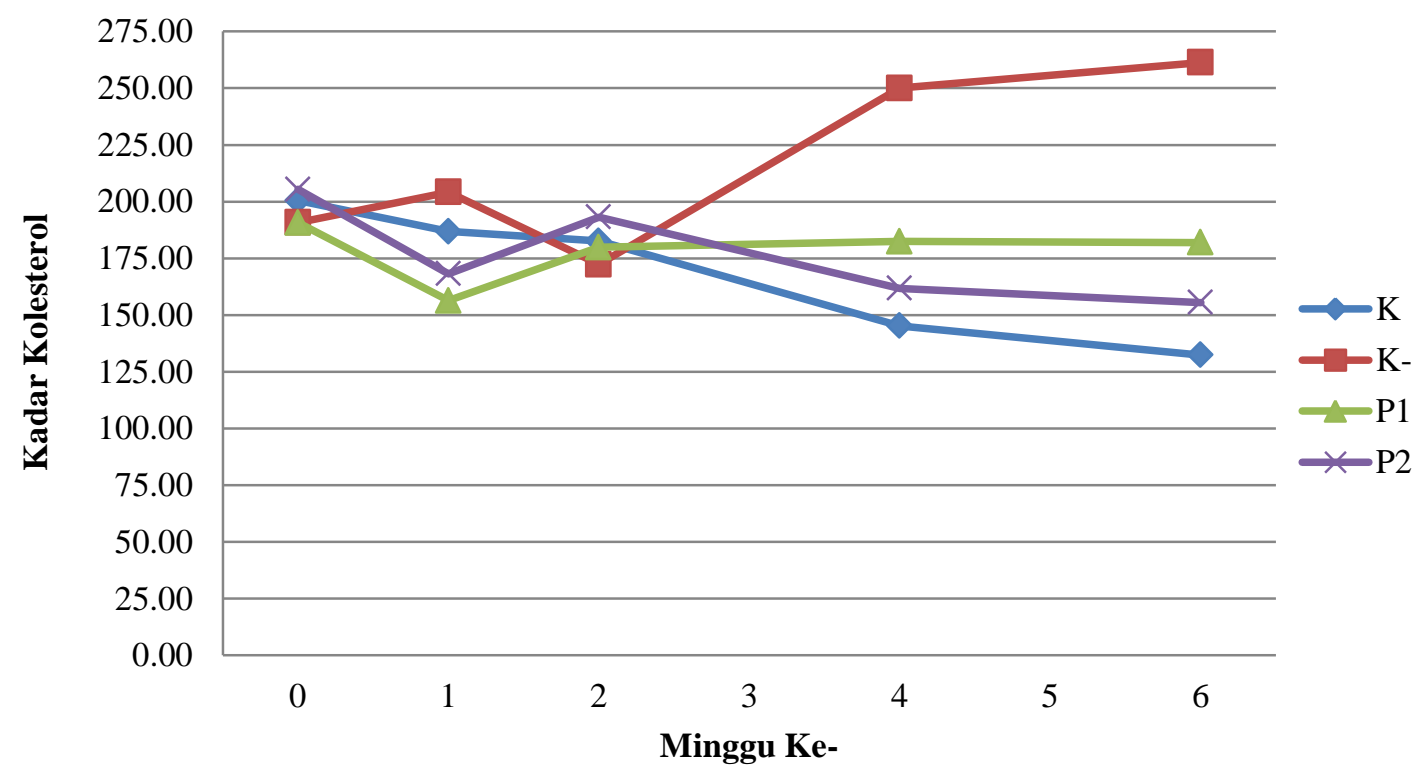

\section{Gambar 1 - Grafik Pengujian Kadar Kolesterol Total}

Pada grafik di atas terjadi penurunan kadar kolesterol total kelompok $\mathrm{K}$ - yang diiringi dengan meningkatnya kadar kolesterol kelompok $\mathrm{P}_{1}$ dan $\mathrm{P}_{2}$ pada pengujian minggu ke-2, yang mungkin disebabkan belum stabilnya kenaikan kolesterol total kelompok perlakuan yang diberi pakan aterogenik. Selain itu, adanya variasi secara genetik sehingga memungkinkan adanya perbedaan respon tubuh yang berbeda terhadap pakan yang diberikan. Hal ini tidak sejalan dengan penelitian yang telah dilakukan
Ariantari et al. (2010) yang melaporkan, kadar kolesterol tikus yang diberikan pakan diet kolesterol tinggi selama 10 hari akan mengalami peningkatan rata-rata $10-20 \mathrm{mg} / \mathrm{dL}$. Selain itu, pemberian pakan hiperkolesterolemia berupa kuning telur, lemak kambing (Gani et al., 2013; Wahyuni et al., 2013) mampu meningkatkan kadar kolesterol darah setelah 14 hari perlakuan.

Peningkatan kadar kolesterol total plasma dalam penelitian ini disebabkan karena meningkatnya 
jumlah konsumsi asam lemak jenuh. Menurut Guyton dan Hall (1996), diet asam lemak jenuh dapat meningkatkan konsentrasi kolesterol darah 15-25\%. $\mathrm{Hal}$ ini disebabkan karena asam lemak dapat diubah menjadi asetil KoA melalui oksidasi $\beta$. Asetil KoA merupakan prekursor kolesterol, sehingga peningkatan jumlah prekursor ini dapat menyebabkan peningkatan kadar kolesterol dalam darah. Hal ini tentu akan berdampak pada terganggunya proses metabolisme dan ekskresi kolesterol di dalam tubuh sehingga kadar kolesterol total serum akan meningkat. Kolesterol total serum terdiri dari VLDL, LDL, HDL dan kolesterol bebas. Peningkatan kolesterol total serum terkait dengan peningkatan VLDL, LDL dan kolesterol bebas (Murray et al., 2003).

Peningkatan kadar kolesterol total terjadi akibat adanya peningkatan kadar asam lemak bebas dalam plasma yang dapat mengakibatkan sekresi VLDL oleh hati, yang meliputi peningkatan kadar triasilgliserol ke dalam sirkulasi darah. VLDL merupakan prekursor pembentukan IDL yang selanjutnya akan menjadi prekursor LDL. LDL bertugas untuk mendistribusikan kolesterol dari hati ke jaringan. Untuk dapat memasuki sel, LDL akan berikatan dengan reseptor LDL ( $r$-LDL) yang terletak pada permukaan membran sel. Peningkatan kolesterol ke dalam sel dapat menurunkan jumlah r-LDL. Penurunan r-LDL dapat menyebabkan jumlah LDL dalam sirkulasi meningkat (Murray et al., 2003).

Pada pemeriksaan kolesterol minggu ke-4, kadar kolesterol total kelompok K- mengalami peningkatan yang diiringi dengan penurunan kadar kolesterol total kelompok $\mathrm{K}, \mathrm{P}_{1}$ dan $\mathrm{P}_{2}$. Penurunan kadar kolesterol total kelompok perlakuan disajikan dalam tabel 3.

Tabel 3 - Penurunan Kadar Kolesterol Total

\begin{tabular}{|c|c|c|c|c|c|}
\hline \multirow{2}{*}{$\begin{array}{c}\text { Kelompok } \\
\text { Perlakuan }\end{array}$} & \multicolumn{4}{|c|}{ Kadar Kolesterol (mg/dL) } & \multirow{2}{*}{$\begin{array}{c}\text { Rata-rata Penurunan Kadar Kolesterol } \\
(\mathrm{mg} / \mathrm{dL}) / \text { Minggu Pengujian }\end{array}$} \\
\cline { 2 - 5 } & 1 & 2 & 3 & 4 & 17,0 \\
\hline $\mathrm{K}$ & 13,60 & 4,20 & 37,40 & 12,80 & $-17,6$ \\
\hline $\mathrm{K}-$ & $-13,34$ & 31,84 & $-77,67$ & $-11,33$ & 2,2 \\
\hline $\mathrm{P}_{1}$ & 34,34 & $-23,50$ & $-2,57$ & 0,40 & 12,5 \\
\hline $\mathrm{P}_{2}$ & 37,20 & $-25,00$ & 31,40 & 6,30 & \\
\hline
\end{tabular}

Keterangan: hasil yang negatif (-) pada tabel ini menunjukan adanya peningkatan kadar kolesterol total. 1: selisih pengujian kadar kolesterol total minggu ke-1 dan minggu ke-0. 2: selisih pengujian kadar kolesterol total minggu ke-2 dan minggu ke-1. 3: selisih pengujian kadar kolesterol total minggu ke-4 dan minggu ke-2. 4: selisih pengujian kadar kolesterol total minggu ke-6 dan minggu ke-4.

Pada penelitian ini dosis terkecil $10 \mathrm{mg} / \mathrm{kgBB}$, sudah dapat menurunkan kadar kolesterol total yang cukup signifikan dibandingkan dengan kelompok K-. Penurunan rata-rata kadar kolesterol total pada kelompok $\mathrm{P}_{1}$ sebesar $2,2 \mathrm{mg} / \mathrm{dL}$ per minggu pengujian, dengan persentase penurunan kadar kolesterol total sebesar $12 \%$.

Pada dosis $30 \mathrm{mg} / \mathrm{kgBB}$, persentase penurunan kadar kolesterol total mencapai $71 \%$ dengan rata-rata penurunan kadar kolesterol total sebesar $12,5 \mathrm{mg} / \mathrm{dL}$ per minggu pengujian. Penurunan kadar kolesterol total ini memiliki hasil yang signifikan dibandingkan dengan kelompok K-. Penurunan kadar kolesterol total ini sendiri belum mampu mengembalikan kadar kolesterol total ke kondisi normal, jika dibandingkan dengan kadar kolesterol total kelompok K. Persentase penurunan kadar kolesterol total disajikan pada tabel 4.

Dari hasil skrining fitokimia yang telah dilakukan, daun patikan emas positif mengandung senyawa fenolik, flavonoid dan steroid. Senyawa fenolik dan flavonoid merupakan senyawa polifenol yang dapat menurunkan kadar kolesterol total dalam darah dengan cara menghambat absorbsi kolesterol oleh usus, meningkatkan reaksi pembentukan dan ekskresi asam empedu melalui feses serta mengurangi kekentalan darah, meningkatkan r-LDL, dan mampu mengikat apolipoprotein sehingga mengurangi terjadinya pengendapan lemak pada pembuluh darah (Carvajal-Zarrabal et al., 2005; Yokozawa et al., 2002).

Tabel 4 - Persentase Penurunan Kadar Kolesterol Total terhadap Kelompok K-

\begin{tabular}{|c|c|}
\hline $\begin{array}{c}\text { Kelompok } \\
\text { Perlakuan }\end{array}$ & $\begin{array}{c}\text { Penurunan Kadar Kolesterol } \\
\text { Total (\%) }\end{array}$ \\
\hline $\mathrm{K}$ & $96 \%$ \\
\hline $\mathrm{P}_{1}$ & $12 \%$ \\
\hline $\mathrm{P}_{2}$ & $71 \%$ \\
\hline
\end{tabular}

Keterangan : $\mathrm{P}_{1}$ : pemberian ekstrak daun patikan emas dengan dosis $10 \mathrm{mg} / \mathrm{kgBB}$. $\mathrm{P}_{2}$ : pemberian ekstrak daun patikan emas dengan dosis 30 $\mathrm{mg} / \mathrm{kgBB}$

Selain senyawa polifenol, steroid tanaman atau fitosterol juga dapat menurunkan kadar kolesterol total. Penelitian yang telah dilakukan oleh Jones et al. (2000) menyatakan bahwa penurunan kolesterol terjadi karena kemampuan fitosterol dan fitostanol untuk menurunkan absorbsi kolesterol, selain itu, secara parsial juga terjadi penekanan biosintesis kolesterol. Nguyen (1999) dan Jones et al. (2000) 
menyatakan bahwa konsumsi fitostanol sebanyak 2-3 g/hari dapat menurunkan total kolesterol dan LDL pada manusia, sedangkan konsentrasi dari HDL serum tidak menunjukkan perubahan secara signifikan. Selain itu, secara intrinsik juga berperan pada modifikasi asetil-KoA karboksilase dan aktivitas 7 - $\alpha$-kolesterol hidroksilase, yang merupakan enzim yang berperan dalam sintesis kolesterol dalam tubuh. Mekanisme aktivitas penurunan kolesterol oleh fitosterol menurut Bonsdorff-Nikander (2005) yaitu, fitosterol diyakini dapat menghambat absorbsi kolesterol eksogen dan reabsorbsi kolesterol endogen dalam saluran pencernaan, meningkatkan pengeluaran kelebihan kolesterol yang diabsorbsi, sehingga menyebabkan penurunan kadar kolesterol serum, serta terjadi kompetisi antara kolesterol dan fitosterol dalam penyerapannya di dalam usus, sehingga mengakibatkan berkurangnya jumlah kolesterol yang diserap oleh tubuh.

\section{Kesimpulan}

Ekstrak etanol daun patikan emas memiliki aktivitas antikolesterol pada dosis 10 dan 30 $\mathrm{mg} / \mathrm{kgBB}$. Dengan aktivitas antikolesterol yang lebih tinggi terdapat pada kelompok tikus wistar dengan pemberian ekstrak daun patikan emas dengan dosis $30 \mathrm{mg} / \mathrm{kgBB}$ dengan penurunan kolesterol sebesar $71 \%$ jika dibandingkan dengan kelompok K(kelompok dengan pemberian pakan aterogenik). Aktivitas penurunan kadar kolesterol total dipengaruhi oleh senyawa fenolik, flavonoid dan steroid yang terkandung di dalam daun patikan emas.

\section{Daftar Pustaka}

Ariantari, N.P., S.C. Yowani, dan D.A. Swastini. 2010. Uji Aktivitas Penurunan Kolesterol Produk Madu Herbal yang Beredar di Pasaran pada Tikus Putih Diet Lemak Tinggi. J. Kimia. 4: 15-19.

Bonsdorff-Nikander, A.V. 2005. Studies on a Cholesterol Lowering Microcrystalline Phytosterol Suspension Oil [Disertasi]. Faculty of Pharmacy, University of Helsinki, Finlandia.

Carvajal-Zarrabal, O., S.M. Waliszewski, D.M. Barradas-Dermitz, Z. Orta-Flores, P.M. HaywardJones, C. Nolasco-Hipolito, O. Angulo-Guerrero, R. Sanchez-Ricano, R.M. Infanzon, dan P.R. Trujillo. 2005. the Consumption of Hibiscus sabdariffa Dried Calyx Ethanolic Extract Reduced Lipid Profile in Rats. Plant Foods Hum. Nutr. 60: 153-159.

Chenoweth, W., M. Ulemann, R. Simpson, dan G. Levielle. 1981. Influence of Dietary Cholesterol and Fat on Serum Lipids in Men. J. Nutrition. 111: 2069-2080.

Das, A.K., A.S.R. Anjaneyulu, R. Thomas, dan N. Kondaiah. 2009. Effect of Different Fats on the Quality of Goat Meat Patties Incorporated with FullFat Soy Paste. J. of Muscle Foods. 20: 37-53.
Delgado, J.N. 1982. Karbohidrat. IKIP Semarang Press, Semarang.

Gani, N., L.I. Momuat, dan M.M. Pitoi. 2013. Profil Lipida Serum Tikus Wistar yang Hiperkolesterolemia pada Pemberian Gedi Merah Abelmoschus manihot L. J. MIPA UNSRAT Online. 2: 44-49.

Guyton, dan Hall. 1996. Buku Ajar Fisiologi Kedokteran. Edisi 9. Penerbit Buku Kedokteran, Jakarta.

Gwynee, J.T., dan B. Hess. 2000. the Role of High Density Lipoprotein in Rats Adrenal Cholesterol Metabolism and Steroidogenesis. J. Biol. Chem. 255: 10875-10883.

Hardiningsih, R., dan N. Nurhidayat. 2006. Pengaruh Pemberian Pakan Hiperkolesterolemia terhadap Bobot Badan Tikus Putih Wistar yang Diberi Bakteri Asam Laktat. Biodiversitas. 7: 127-130.

Holm, L.G., J. Doll, J. Potiche, dan J. Hamburger. 1997. World Weeds: Natural Histories and Distribution. John Wiley \& Sons, Inc., USA.

Jones, P.J., M. Raeini-Sarjaz, F.Y. Ntanios, C.A. Vanstone, J.Y. Feng, dan W.E. Parsons. 2000. Modulation of Plasma Lipid Levels and Cholesterol Kinetics by Phytosterol versus Phytostanol Esters. J. Lipid Res. 41: 697-705.

Murray, R.K., D.K. Granner, P.A. Mayes, dan V.W. Rodwell. 2003. Biokimia Harper. Edisi 25. Penerbit Buku Kedokteran, Jakarta.

Nafrialdi, S. 2007. Farmakologi dan Terapi. Edisi ke-5. Gaya Baru, Jakarta.

Nguyen, T.T. 1999. The Cholesterol Lowering Action of Plant Stanols Esters. J. Nutr. 129: 2109-2112.

Richardson, P.E., M. Machekar, N. Dashti, M.K. Jones, A. Beigneux, S.G. Young. 2005. Assembly of Lipoprotein Particles Containing Apolipoprotein-B: Structural Model for the Nascent Lipoprotein Particle. Biophy. J. 88: 2789-2800.

Saidin, M. 1999. Kandungan Kolesterol dalam Berbagai Bahan Makanan Hewani. Bul. Penelitian Kesehatan. 27: 224-230.

Soedarsono, dan U. Atmomarsono. 1983. Peran Kolesterol dalam Makanan. Wartazoa. 1: 35-37.

Thacker, A.K., S. Saxena, J. Khan, dan S.P. Saxena. 2005. Lipid Abnormalities Associated with Stroke. Annals. Ind. Acad. Neuro. 8: 133-138.

Visavadiya, N.P., Narasim, dan A.V.R.L. Hacharya. 2005. Hipolipidemic and Antioxidant Activities of Asparagus recemous in Hypercholesterolemic Rats. Ind. J. Pharmacol. 37: 376-380.

Wahyuni, F.D., I.N. Asyiah, dan S. Hariyadi. 2013. Pengaruh Ekstrak n-Heksana Daging Buah Delima Putih (Punica granatum) terhadap Penurunan Kadar Kolesterol Darah pada Tikus Putih (Rattus norvegicus L.) dan Pemanfaatannya sebagai Buku Suplemen. Pancaran. 2: 89-99.

Yokozawa, T., T. Nakagawa dan K. Kitani. 2002. Antioxidative Activity of Green Tea Polyphenol in 
